Grand Valley State University

ScholarWorks@GVSU

Peer Reviewed Articles - Hospitality and Tourism Management

Hospitality and Tourism Management

$4-25-2016$

\title{
Food Recovery Program at Farmers' Markets Increases Access to Fresh Fruits and Vegetables for Food Insecure Individuals
}

Lisa G. Sisson

Grand Valley State University, sissonl@gvsu.edu

Follow this and additional works at: https://scholarworks.gvsu.edu/htm_articles

Part of the Nutrition Commons, and the Social and Behavioral Sciences Commons

\section{ScholarWorks Citation}

Sisson, Lisa G., "Food Recovery Program at Farmers' Markets Increases Access to Fresh Fruits and Vegetables for Food Insecure Individuals" (2016). Peer Reviewed Articles - Hospitality and Tourism Management. 2.

https://scholarworks.gvsu.edu/htm_articles/2

This Article is brought to you for free and open access by the Hospitality and Tourism Management at ScholarWorks@GVSU. It has been accepted for inclusion in Peer Reviewed Articles - Hospitality and Tourism Management by an authorized administrator of ScholarWorks@GVSU. For more information, please contact scholarworks@gvsu.edu. 


\title{
Food Recovery Program at Farmers' Markets Increases Access to Fresh Fruits and Vegetables for Food Insecure Individuals
}

\author{
Lisa G. Sisson
}

Department of Hospitality and Tourism Management, Grand Valley State University, Grand Rapids, Michigan, USA

\begin{abstract}
Food recovery programs are an increasingly popular method to decrease the amount of food waste in the United States while increasing healthy food access for food insecure individuals. One such program is the Heartside Gleaning Initiative that began in 2014 in Grand Rapids, Michigan. The program partners with low-income volunteers to collect fresh produce from farmers' markets for redistribution. From June to October 2014, 17,000 pounds of fresh produce was provided to low-income individuals and food pantries. A survey of participants indicated high usage of the produce and high satisfaction with the gleaning program. This program confirms that gleaning is a viable method of reducing barriers to accessing produce for food pantries and food insecure individuals.
\end{abstract}

\section{PROGAM OBJECTIVES}

Food recovery programs are an increasingly popular method to decrease the amount of food waste in the U.S. while increasing healthy food access for food insecure individuals. In the Heartside neighborhood of downtown Grand Rapids, Michigan, approximately $70 \%$ of residents experience some degree of food insecurity, liquor stores and gas stations are the only locations to purchase fresh fruits and vegetables (FFV), and fewer than $50 \%$ of households have access to a car for ease of shopping. Greater than $65 \%$ of the population lives below $150 \%$ of the federally defined poverty level (approximately $\$ 16,000$ for a single-person household in $2010^{1}$ ) and the unemployment rate is $25.2 \%$. $^{2}$ Non-profit organizers working in Heartside recognized that a gleaning program with neighborhood involvement might be successful in providing FFV to those in the neighborhood. To assess the viability of a gleaning program, farmers at two local farmers' markets were queried and many indicated they would be willing to donate unsold produce at the close of the Saturday market. The resulting Heartside Gleaning Initiative (HGI) promotes healthy eating by gleaning produce from farmers' markets and redistributing it in Heartside and surrounding neighborhoods. The foremost goal of the program is to increase access to FFV, but HGI also strives to promote sustainable food systems by reducing food waste. Additionally, this program provides meaningful volunteer opportunities for under- and unemployed neighborhood residents, while empowering them to improve their health. 


\section{IMPLEMENTATION PROCESS}

HGI volunteers, consisting of neighborhood residents, students, and other community members, glean and distribute produce every Saturday, June through October. Volunteers go to two area farmers' markets where they collect, weigh, and record produce donations, and then deliver the gleaned FFV to a low-income apartment complex where more volunteers assist with the distribution process. Complex residents and neighbors select what they want from the produce displayed on tables. A volunteer dietitian prepares and provides recipe samples made from gleaned produce and ingredients commonly found at food pantries. The volunteers then assist with transporting the remaining produce to neighborhood food pantries and meal programs.

\section{OUTCOMES}

The HGI program was highly successful in its first year with donations from 40 farmers of more than 17,000 pounds and 35 varieties of FFV distributed to low-income recipients. One resident volunteer said, "We can actually see from week to week what these donations are doing. The biggest thing for me is that kids are now getting food that their parents normally can't afford. Families need to buy necessities, and fruits and vegetables are considered a luxury. You can see the gratitude in their faces."

\section{EVALUATION}

A small sample survey of participants $(n=17)$ found $70 \%$ used $100 \%$ of the produce received, $87 \%$ shared produce with others, $100 \%$ agreed that the quality of the produce was average to very good and $100 \%$ were satisfied with the program. Food pantries and meal programs that received food reported very high satisfaction and $0 \%$ waste. Further program assessment should evaluate changes in FFV consumption, self-efficacy, and food security status in volunteers and participants, and the impact on food waste reduction, community partnerships, public relations and tax deductions for farm donors. This program confirms gleaning is a viable method of reducing barriers to accessing FFV for food pantries and food insecure individuals. 


\section{References}

1. Aspe.hhs.gov. August 2010 HHS Poverty Guidelines. 2015. Available at: http://aspe.hhs.gov/poverty/10poverty.shtml. Accessed June 25, 2015.

2. Johnson Center at Grand Valley State University Community Profiles. Available at http://weave.cridata.org/communityprofiles/. Accessed December 20, 2014. 